
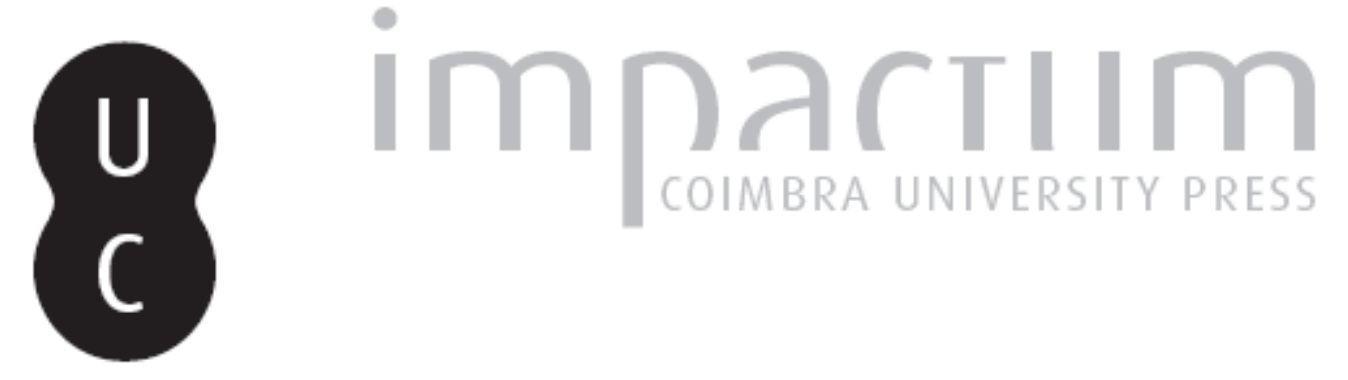

\title{
Teaching by example: aetiology in Plutarch's De mulierum uirtutibus
}

Autor(es): $\quad$ Benefiel, Rebecca R. J.

Publicado por: International Plutarch Society

URL persistente:

URI:http://hdl.handle.net/10316.2/37571

DOI:

DOI:http://dx.doi.org/10.14195/0258-655X_1_1

Accessed : $\quad$ 26-Apr-2023 12:21:53

A navegação consulta e descarregamento dos títulos inseridos nas Bibliotecas Digitais UC Digitalis, UC Pombalina e UC Impactum, pressupõem a aceitação plena e sem reservas dos Termos e Condições de Uso destas Bibliotecas Digitais, disponíveis em https://digitalis.uc.pt/pt-pt/termos.

Conforme exposto nos referidos Termos e Condições de Uso, o descarregamento de títulos de acesso restrito requer uma licença válida de autorização devendo o utilizador aceder ao(s) documento(s) a partir de um endereço de IP da instituição detentora da supramencionada licença.

Ao utilizador é apenas permitido o descarregamento para uso pessoal, pelo que o emprego do(s) título(s) descarregado(s) para outro fim, designadamente comercial, carece de autorização do respetivo autor ou editor da obra.

Na medida em que todas as obras da UC Digitalis se encontram protegidas pelo Código do Direito de Autor e Direitos Conexos e demais legislação aplicável, toda a cópia, parcial ou total, deste documento, nos casos em que é legalmente admitida, deverá conter ou fazer-se acompanhar por este aviso.

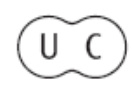




\title{
TeaChing BY EXAMPLe Aetiology in Plutarch's De Mulierum Virtutibus \\ by \\ Rebecca R. J. Benefiel \\ Harvard University
}

\begin{abstract}
In this paper, I propose that aetiology was central to Plutarch's essay, De Mulierum Virtutibus. Within this series of examples illustrating women's virtues, Plutarch concludes many of the episodes with an aetiology. A careful examination of these aetiologies and their distribution throughout the work reveals both the importance of this device and the sophisticated manner in which Plutarch employs it. I suggest this use of aetiology is the main mechanism for proving his argument that women and men can display the same virtue. The aetiologies legitimize this claim by proving that women's actions had real consequences, the effects of which could even reach his contemporary audience.
\end{abstract}

This paper will examine one device that Plutarch uses to educate his reader and communicate a shared sense of culture, namely, his use of aetiology. As early as the archaic period aetiology served a didactic function in Greek culture, often within the religious sphere. From the Homeric Hymns to tragedy to the works of Callimachus, aetiology was used to explain a present phenomenon, a festival, custom, or object, in terms of a past occurrence. Within this tradition, Plutarch found aetiology a useful and flexible rhetorical tool and he employed it in a number of his works for a range of purposes. For example, into his Life of Theseus Plutarch incorporates about thirty aetiologies, many of which pertain to the topography and institutions of Athens. These concern Theseus as the founder of Athens and provide a semi-historical basis for his legendary life. Plutarch's interest in aetiology is also clearly evident in his Greek Questions and Roman Questions

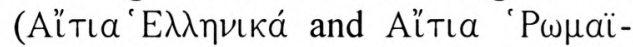
$\kappa \alpha ́)$. These works each consist of a string of aetiologies, structured as a series of questions and possible answers that pertain to the origins and causes of institutions or specific naming conventions.

In the essay De Mulierum Virtutibus, Plutarch uses aetiology in yet another manner and for a, different purpose. In this paper, I propose that his use of aetiology in this work is the main mechanism for proving his argument that 
women and men can display the same virtue. In arguing this point, Plutarch contributes to a continuing debate that dated back to the time of Socrates. To support his opinion, Plutarch offers illustrations of women's virtue, but he does not limit the examples to only Greek women or even to Greek and Roman women; rather, his examples demonstrate the virtue of women from Greece to Salamantica and from Etruria to Persia. In addition to the examples of virtue, Plutarch includes an aetiology at the end of many episodes. I suggest that these aetiologies are central to Plutarch's argument. The aetiologies legitimize his claim regarding the nature of virtue both by illustrating that women can display the same virtues as men and by proving that their actions have real consequences that may even affect his contemporary audience. Despite the fact that Plutarch often offers programmatic statements about his aims and methodology, he says nothing about his use of aetiologies. A careful examination of the aetiologies in this work, however, reveals both the importance of this device and the sophisticated manner in which Plutarch employs it. I will begin by considering what Plutarch does say about his methodology for the De Mulierum Virtutibus. I will then define and identify the aetiologies included in this essay and will subsequently' consider their distribution throughout the work. Finally, I will examine how these aetiologies are employed to support Plutarch's argument and what effects they bring about.

In the extended preface that opens the essay, Plutarch puts forth his motivation for composing this work, his aim in writing it, and the reasoning behind his structure of the work. The death of Leontis, whom Plutarch judged to be a woman of arete, occasioned a discussion concerning the virtues of women. $\mathrm{He}$ addresses the Delphic priestess, Clea, writing that this essay consists of his further thoughts on the subject, and he states clearly that the aim of the work is to prove that the virtue of women and men is one and the same:

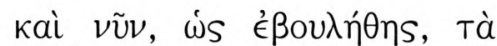

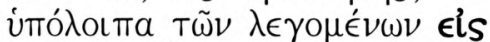
Tò $\mu$ lav Elval kai Tìv aưTìv

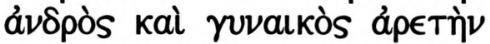

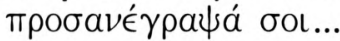

And now, as you wished, I have written out for you the rest of the things I would have said concerning the virtue of men and women being one and the same... (243A)

Plutarch then justifies his methodology: if he were to compare the poetry of women and men, would he not put their

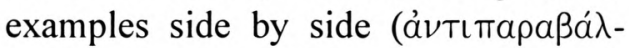
$\lambda \omega)$ ? Paintings could be compared in the same way. Indeed one recognizes the familiar strategy employed for his Parallel Lives when he suggests the best way to compare the virtues of men and women is to compare Bíor with Bior (lives with lives) and $\pi \rho a ́ \xi \in \in$ IS with 
$\pi \rho a ́ \xi \in l s$ (deeds with deeds) ${ }^{1}$. The essay that follows does not take the same form as the Parallel Lives, however. Rather than contrasting men's with women's deeds, it focuses on offering examples of women's virtue. The body of the work is a long series of self-contained episodes, first, of groups of women displaying virtue or bravery, then, of the virtuous acts of individual women. Plutarch does justify his structure for the work with this preface, but nowhere does he mention his use of the device of aetiology.

Before we consider the aetiologies in this work, however, it will be helpful to define the criteria for identifying an aetiology. In a recent article, Hayden Pelliccia proposed a definition for aetiological syntax as consisting of: "the juxtaposition...of [a] statement of an event in the past and [a] statement, in the present tense or equivalent, of a perpetually true condition vel sim. following from it" ${ }^{\prime 2}$. This can be rendered through either paratactic or hypotactic constructions. In the De Mulierum Virtutibus, the aetiology from the episode of the Women of Argos (episode \#4) ${ }^{3}$ offers one such example of a hypotactic construction:

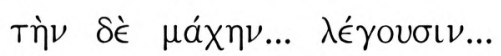

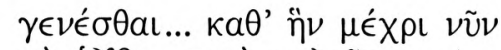

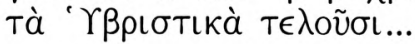

They say the battle took place (on the day) on which even until today they celebrate the Hubristika. (245E)

The celebration of the festival is therefore the present condition that results from the past event of the battle. In addition to such syntax, the hypotactic constructions in this essay often appear in conjunction with certain vocabulary. For example, the phrase $\mu \epsilon ́ x \rho \iota ~ \nu \tilde{v} \nu$ in the passage above highlights the aetiology further by emphasizing a specific connection with the pres-

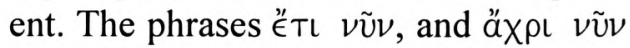
(even now, or up to now) appear in other episodes with the same function ${ }^{4}$.

Alternately, in a paratactic construction, a demonstrative can be used to connect an action with its result. The episode of the Persian Women (\#5) provides such an example, concluding with the following statement:

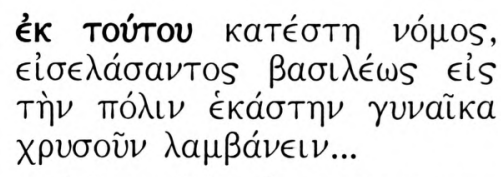

From this, the custom was established that whenever the

\section{B-C.}

H. Pelliccia, 1989, pp. 74-75.

3 The table at the end of this paper gives a full account of the aetiologies in the De Mulierum Virtutibus.

4

Hypotactic constructions for aetiologies occur in episodes $2,4,16$, and 18, often in conjunction with these phrases (which appear in episodes 1, 2, 4, and 16). 
king drove into the city, each woman would receive a gold (coin)... (246B)

As Pelliccia suggests, the force of the demonstrative phrase ('́к тоÚTOU) in this context is able to convey both a causal and a temporal meaning. It could therefore be most aptly rendered: because of this and ever since this, the custom was established... ${ }^{5}$ This phrase occurs in multiple episodes of this essay, as does the conjunction $\delta$ tó (wherefore, or on what account), which fulfills the same function ${ }^{6}$.

With the application of this aetiological syntax and vocabulary to identify the presence and location of aetiologies in the De Mulierum Virtutibus, one finds that of the twenty-seven episodes Plutarch lists to illustrate the virtue of women, eleven include at least one aetiology. The prevalence of aetiologies among more than one-third of the episodes is already striking, but their distribution is even more remarkable. The aetiologies are distributed within each of the two sections of the work, occurring both times at the beginning of the section. They appear in eight of the first nine episodes on the virtues of groups of women and in the first three episodes on the virtues of individual women (see table). It is therefore not unreasonable to suppose that there is a particular motivation for the prevalence of this device and for such a closely grouped distribution.

The aetiologies given in the different episodes are themselves not uniform. Some account for the institution of festivals; others explain foreign customs. They concern many different nationalities of women (from Greek to Persian and Celtic) in a wide range of time periods. Almost all of the aetiologies, however, are directly connected to the women's display of courage or virtue, and the majority of them also appear at the end of the episode as its concluding statement.

The first three episodes of the work, however, include aetiologies with a slight variation in their positioning. These aetiologies appear at the end of the first episode, at both the beginning and the end of the second episode, and at the beginning of the third episode. The first instance of an aition appears at the end of episode 1 (the Trojan Women), and accounts for the custom of Roman women greeting their relatives with a kiss ${ }^{7}$. After this, Plutarch presents the

PELliCCIA, 1989, pp. 75-76. ÉK TOÚTOU appears in the aetiologies concluding episodes 5 , 6 , and 17.

$6 \Delta$ เó concludes episodes 1,8 , and 9. I cite here the example of episode 9, the Lycian

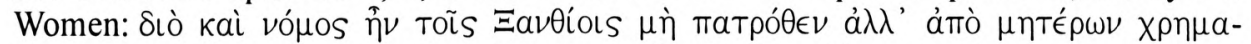
Ti $\zeta \in L \nu$ ("Wherefore, it was also the custom for the Xanthians to take their names not from their fathers but from their mothers.") (248D).

7

$244 \mathrm{~A}$. 
second episode, the Women of Phocis, introducing it with a reference to the magnitude of the women's deed as, he states, "...is attested both by great sacred rites which the Phocians still perform near Hyampolis even now and by ancient decrees" (244B). Plutarch then returns to the aetiology at the end of the narrative and uses it to conclude the episode. The women of Phocis had voted and agreed to sacrifice themselves on a pyre in the case of Phocian defeat in battle. Victory negated the need for sacrifice, and Plutarch concludes:

Tò $\mu \grave{v} \nu$ oûv $\psi n ́ \phi ı \sigma \mu a ~ \Phi \omega-$

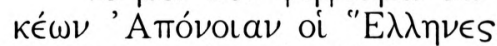

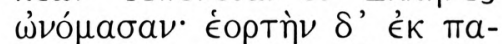

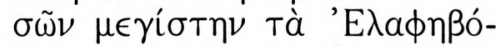

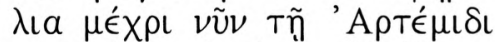

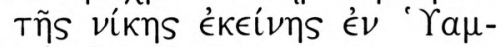

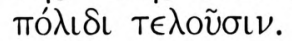

To this vote of the Phocians the Greeks gave the name of 'Desperation'; and the greatest festival of all, the Elaphebolia in honour of Artemis, they celebrate in Hyampolis even to this day in commemoration of that victory. (244D-E) ${ }^{8}$

Next follows the third episode and this too begins with immediate mention of a cause (an aitia). This episode of the Women of Chios begins: "The Chians settled Leuconia for the following rea-

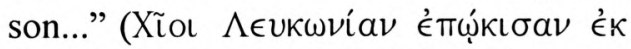
тolaútns aitías... 244E). This has a different form than the other aetiologies. This phrase introduces the background for the narrative, but it does not have the aetiological syntax or vocabulary that we encounter elsewhere. Nor is it connected with the illustration of the Chian women's virtue which appears later in the episode. Nevertheless, by beginning the episode with this type of terminology and by putting an emphasis on the cause of something, Plutarch continues to weave the thread he has used to tie together the episodes up to this point. Specific cause and effect references act as transitional statements for the first three episodes. After this narrative, the eight remaining aetiologies all appear as the conclusions of their respective episodes. It may be the case, therefore, that there has been a conscious attempt -especially at the beginning of the work- to make the point that specific consequences follow the women's actions.

I offer a brief summary of each of the next five aetiologies. The fourth episode, concerning the Women of Argos, includes two aetiologies. First, the festival of the Hubristika continues to be celebrated as the commemoration of a battle won by women's strength and courage (245E). Then, added as though a corollary to the story, a second aition explains an unusual law and makes a case against a passage of Herodotus 
$(245 \mathrm{~F})^{9}$. The next four aetiologies all explain certain customs and pertain to groups of women outside the mainland of Greece. To begin, the steadfastness of the Persian Women $(\# 5,246 \mathrm{~B})$ brought about a special honor for them any time the king entered town; then, the just arbitration of the Celtic Women (\#6, 246C) avoided civil war and thereafter secured them a position of authority for decisions of foreign policy; the Tyrrhenian Women's daring (\#8, 247F) to take the place of their husbands in jail led to the concession of the Spartans to their husbands and to the perceived identity of this group as both Athenian and Spartan; and, finally, the Lycian Women's shaming of Bellerophon (\#9, 248D) saved the country when the men could not and so accounts for the Lycian custom of bearing names of matrilinear descent rather than patronymics.

Within this series of examples of women's virtue, it is perhaps significant that the one episode that does not include an aetiology does end with a concluding statement that would seem to perform a similar function. In the seventh episode, the Women of Melos save their men by accompanying them to a dinner and carrying hidden weapons for them. Plutarch concludes the episode with the following statement:

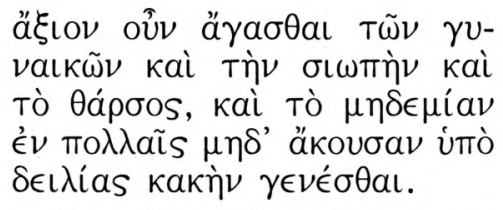

It is right and good to admire both the silence and the daring of the women, and the fact that, among so many, not one of them could be spoken ill of on account of cowardice. (247A)

This type of gnomic statement (ä $\xi \circ v$

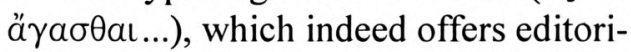
al comment, has not appeared earlier in the work ${ }^{10}$. It seems worthy of note that it does appear here, in the same position as the aetiologies of the other episodes, as if some authoritative statement were necessary to anchor the narrative by illustrating the consequences and proving the gravity of the women's actions. The eleventh episode appears to have a similar gnomic statement summarizing and drawing general conclusions about the behavior of the Women of Miletus.

The remaining episodes concerning groups of women, however, are without aetiologies. After the fifteenth episode, Plutarch adds a transitional statement noting that he will now offer examples

For elaboration on the various traditions concerning the loss of Argive men and the resulting unions of the Argive women, see Stadter, 1965, p.50.

10 K. BLOMQVist, 1997, pp.73-97, uses other passages, including several episodes from the Parallel Lives, to distill Plutarch's attitudes towards women. This passage would seem to support her conclusions that Plutarch admires women who can show strength and courage, so long as they do not try to remain permanently active in the political sphere. 
of individual women's displays of virtue. $\mathrm{He}$ remarks also that he will record these episodes in no set order but merely as they come to him, since the subject matter does not require a chronological order. (In point of fact, the episodes for the groups of women were not arranged in chronological order either.) With this specific statement regarding the ordering of the episodes, it is interesting to note that the first three of the twelve episodes that follow each include aetiologies.

The design of these aetiologies is reminiscent of the ordering of the aetiologies at the beginning of the work. The episode on Pieria (\#16) ends with honor and repute for her, "with the result that the women of Miletus pray even to this day (äX $\rho\llcorner\nu \tilde{v} v)$ that their husbands may love them as much as Phrygius loved Pieria" $(254 \mathrm{~B})^{11}$. Once the connection with the present day has been re-established, the next aetiology has different

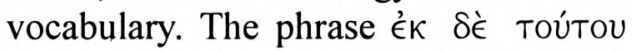
connects the bravery of Polycrite (\#17) with the reconciliation between the Naxians and Milesians. Finally, after foiling a treacherous plot, Lampsace (\#18) is honored after her death by having the city renamed after her; she is also voted heroic honors, which are later upgraded to the divine honors that are continued to the present.

Having examined these aetiologies and their distribution within Plutarch's De Mulierum Virtutibus, I propose that the rhetorical device of aetiology was integral to Plutarch's essay. In this work, Plutarch entered into the controversial debate over the nature of virtue, a debate in which Thucydides, Plato, and Aristotle had taken part ${ }^{12}$. He used the device of aetiology to support his own position and to lend weight to his argument. These aetiologies prove not only that women can and do display virtue and daring equal to men's, but also that women's virtue can have important consequences.

In his preface, Plutarch already expresses an awareness that his audience might consider the topic of women's virtue as insubstantial. He faces the charge, however, with the defense that the work "has historical exposition and is not arranged for the purpose of pleasure for its hearer" ${ }^{13}$. It may produce pleasure by its very nature and so much the better, but he points out that such is not its primary purpose. Structurally, the $D e$

trans. F. C. BABBitT, Plutarch's Moralia, vol. III, Loeb Classical Library, Cambridge: Harvard University Press, 1931.

Thuc., II 45, Pl., Meno 73A-B, Arist., Politics 1259b1-1260a31; For the full background on this debate, ranging from Socrates to Musonius Rufus, see P. STADTER, Plutarch's Historical Methods: An Analysis of the Mulierum Virtutes, Cambridge, MA, 1965, esp. pp. 3-5.

trans. F. C. BABBITT, Plutarch's Moralia, vol. III, Loeb Classical Library, Cambridge:

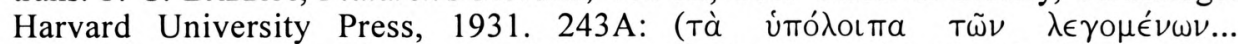

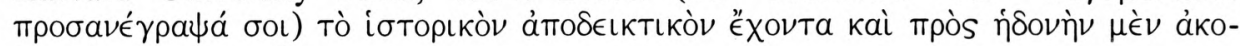

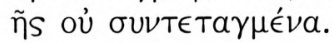


Mulierum Virtutibus has a simple presentation. After the preface opens the work and sets out its aim, a series of examples follow to illustrate the point. There is no conclusion to the work, so it is assumed that the examples themselves will prove the thesis. The underlying structure is more complex. While the examples of virtue do provide the evidence for the argument, it is the application of aetiology which supplies the proof.

We have already seen how the first three episodes of the work are all connected, tied together with an emphasis on aetiology. In addition, the early aitia all emphasize the connection of the women's actions to Plutarch's present time. The vocabulary of the first four episodes emphasizes this relationship with the phrases étı $\nu \tilde{v} \nu$ (even now) and $\mu \epsilon ́ x \rho \iota ~ \nu \tilde{v} \nu$ (up to now) as customs and festivals continue being celebrated into the present. This shows more than the consequences of women's actions; it creates a personal connection for Plutarch's audience with these women who had displayed virtue. The fact that women display virtue and courage equal to men's cannot be ignored when these feats of courage are demonstrated to have had an impact on the present circumstances and life of Plutarch's own audience.

Once Plutarch has reiterated this connection with the present, he is free to provide other aetiologies that have effected different results. The syntax changes and the phrases é $\kappa$ Toútou (because of this) and $\delta$ to (therefore, the cus- tom was... and so on) are more prevalent. While this phrasing still points to a definite consequence resulting from the women's action, these aetiologies do not necessarily show a connection of the past to the present of his audience. This is true also because a number of these episodes illustrate the virtues of non-Greek women. Such illustrations reveal that Plutarch considers virtue to be the same not only for men and women but also for Greek and non-Greek. The women's actions still effect results; however, these results affect other peoples.

The seventh episode, in which a gnomic statement takes the place of an absent aetiology, also reveals the importance of the aetiology to Plutarch's method. At this point in the work, it would seem that Plutarch is not yet confident enough to leave his readers to draw their own conclusions from the examples he provides. However, he has no aetiology to relate to the episode. Therefore, he concludes the episode with a gnomic statement that stresses the importance of the women's virtue and that supports his argument, with the explicit statement, "It is good to honor the courage of women". By about the tenth episode, however, the point has been made. It is no longer necessary to include aetiologies pointing to the magnitude of the women's action. Rather, additional examples are cited to further illustrate the argument and to make the point through an accumulation of evidence. 
When Plutarch reaches the second section of the work, however, and he shifts to citing examples of virtues displayed by individuals, once again the argument must be legitimized. The first few episodes of this section, therefore, again include an aetiology as additional support. And again, as was the case earlier in the work, once the point has been made that these exempla are worthy of study, additional illustrations of virtue may be added without the need for elaboration.

In conclusion, aetiology was a flexible rhetorical device for Plutarch. In the De Mulierum Virtutibus, he uses it to reinforce and prove his argument that women can show the same type of virtue as men. The use of this device would only work to support his argument, however, if his audience readily understood the significance and ramifications of an aetiology. Such could be expected, as aetiologies had long been a part of
Greek culture, important especially in the ethical and religious spheres. Plutarch could thus rely on the traditional force of this device while suiting it to his own purposes. In this work, Plutarch used aetiology as a didactic tool. He drew on a tradition and a cultural heritage that was familiar to his audience and through the device of aetiology he sought to educate his readers about the virtues of women.

\section{BIBLIOGRAPHY}

K. Blomevist,

- "From Olympias to Aretaphila: women in politics in Plutarch," in J. Mossman (ed), Plutarch and his Intellectual World, London, 1997, pp. 73-98.

H. Pelliccia, H.,

- "Pindar, Nemean 7.31-36 and the Syntax of Aetiology," HSCP, 92 (1989) 71-101.

STADTER, P. A.,

- Plutarch's Historical Methods: An Analysis of the Mulierum Virtutes, Cambridge, MA, 1965. 
REBECCA R. J. BENEFIEL

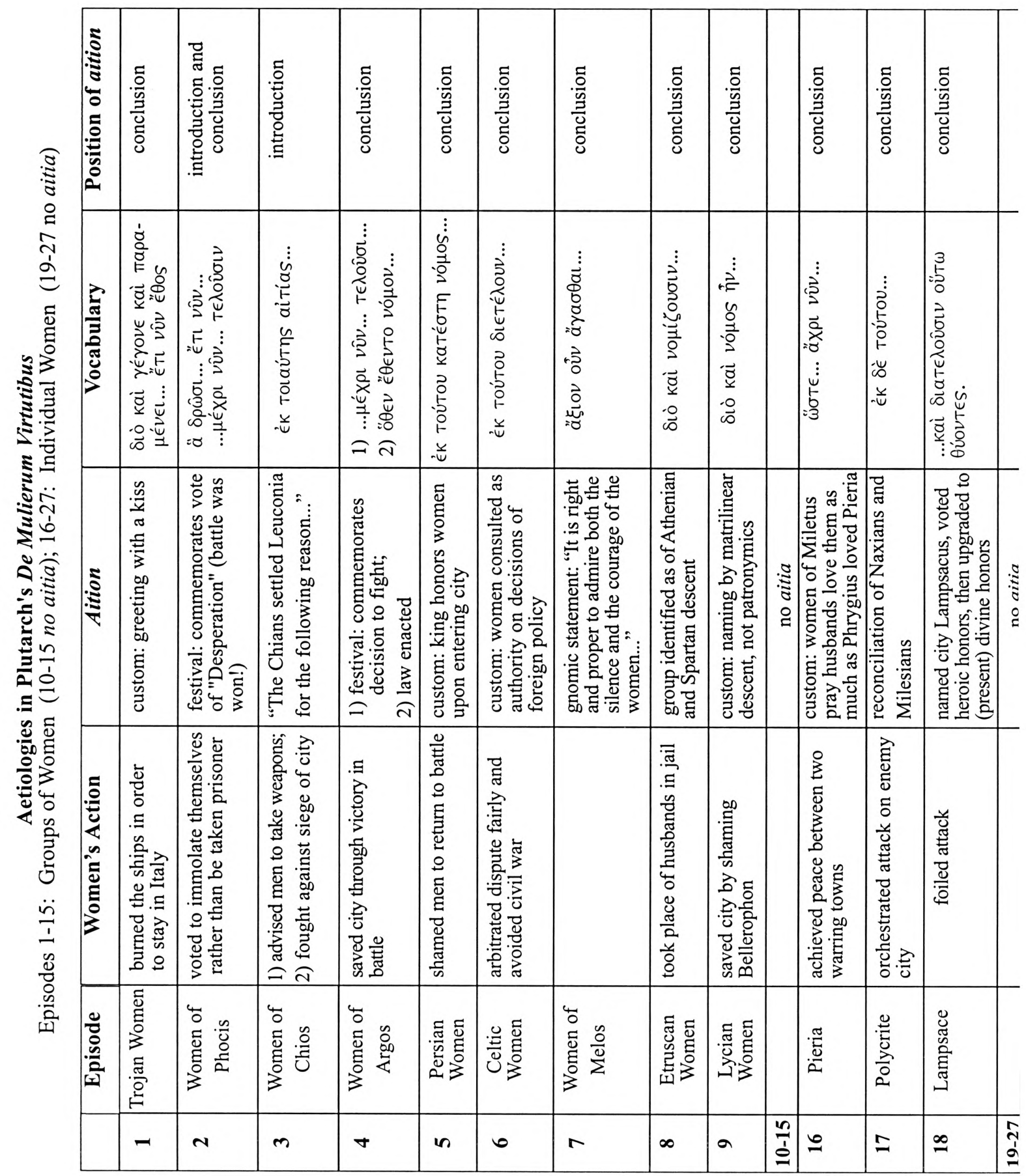

